\title{
Wound healing activity of Allium cepa L. bulbs in a second-degree burn wound model in Holtzman rats
}

\author{
Actividad cicatrizante de los bulbos de Allium cepa L. en un \\ modelo de quemadura de segundo grado en ratas Holtzman
}

Ana María Guevara-Vásquez ${ }^{1 *}(\mathbb{0}$, Carmen Luisa Marín-Tello1]

\begin{abstract}
Background: The bulb of Allium cepa Linnaeus (onion) is used in traditional medicine as an antidiabetic, antioxidant, antihypertensive, anti-inflammatory, and antihyperlipidemic, among others. The lack of information or little knowledge about the effects of Allium cepa L. on skin lesions, specifically burn wounds, arouses interest in studying its effects on these skin disorders. Objective: This study assessed the wound healing activity of Allium cepa L. on second-degree burns induced in Holtzman rats. Method: Thirty-two albino rats were randomly distributed into four groups of 8 rats each, including the Healthy group, the Control group, the Experimental group (Allium cepa L.), and the Standard group (1\% silver sulfadiazine). Burn wounds were induced, and topical treatments were performed daily for 21 days. The reduction of the burned body area $\left(\mathrm{mm}^{2}\right)$ was determined during the experimental time. Albino rats were sacrificed with an excess of surgical anesthesia to obtain tissue samples for histopathological analysis. Results: Standard and experimental groups significantly reduced burned body area $(p<0.01)$ compared to the control group. Histopathological studies showed hyperemic chorion in the Control group, fibroblasts, and collagen in the Standard group, and dermis composed of a reticular stratum of fibroblasts, collagen, and few blood vessels in the Experimental group. Conclusion: Allium cepa L. revealed wound-healing activity on burns induced in Holtzman rats and reduced the damage produced by burns.
\end{abstract}

JOURNAL VITAE

School of Pharmaceutical and Food Sciences ISSN 0121-4004 | ISSNe 2145-2660 University of Antioquia Medellin, Colombia

Filliations

1 Department of Pharmacology, Faculty of Pharmacy and Biochemistry, Universidad Nacional de Trujillo, Av. Juan Pablo II s/n, Trujillo, La Libertad,

*Corresponding

Dr. Ana María Guevara-Vásquez aguevara@unitru.edu.pe

Received: 27 March 2021 Accepted: 08 June 2021 Published: 13 August 2021
Keywords: Burn; Allium cepa L; Phytochemicals; Silver sulfadiazine, Histology.

\section{RESUMEN}

Antecedentes: El bulbo de Allium cepa L. (cebolla) se utiliza en medicina tradicional como antidiabético, antioxidante, antihipertensivo, antiinflamatorio, anti hiperlipidémico entre otros. La falta de información o muy poco conocimiento acerca de los efectos de Allium. cepa L. en lesiones cutáneas, específicamente en las heridas por quemaduras, despierta el interés por estudiar sus efectos en estas afectaciones cutáneas. Objetivo: El objetivo de este estudio fue evaluar la actividad cicatrizante de Allium. cepa L. en quemaduras de segundo grado inducidas en ratas Holtzman. Método: Se utilizaron treinta y dos ratas albinas distribuidas al azar en cuatro grupos de ocho ratas cada uno, incluyendo el Grupo sano, el Grupo Control, el Grupo Experimental (Allium cepa L.) y el Grupo Estándar (Sulfadiazina de plata al 1\%). Se indujo la herida por quemadura, y los tratamientos tópicos se realizaron diariamente durante 21 días. La reducción del área corporal quemada $\left(\mathrm{mm}^{2}\right)$ se determinó durante el tiempo de experimentación, luego los animales fueron sacrificados con exceso de anestesia quirúrgica para obtener las muestras de tejidos para el estudio histopatológico. Resultados: Los grupos estándar y experimental mostraron reducción significativa en el área corporal quemada $(p<0,01)$ comparadas al grupo control. El estudio histopatológico evidenció corion hiperémico en el grupo control; fibroblastos y colágeno en el grupo estándar y dermis integrada por un estrato reticular de fibroblastos, colágeno y pocos vasos sanguíneos en el grupo experimental. Conclusión: Allium cepa L. reveló actividad cicatrizante en quemaduras inducidas en ratas Holtzman, y disminuyó el daño producido por las quemaduras.

Palabras clave: Quemadura; Allium cepa L; Fitoquímicos; Sulfadiazina de plata; Histología. 


\section{INTRODUCTION}

Burn causes damage to the skin, generating a loss of cells and tissues, which can complicate and worsen the health of patients (1). The damage produced in these circumstances involves protein denaturation, necrosis, and exudates, creating congestion and edema and altering cellular and humoral defenses (2).

Worldwide, burns are a public health problem, producing 180,000 deaths annually, especially in low- and middle-income countries (3). In Peru, approximately 15,000 cases of burned children are reported each year, of which 130 per year have severe burns from hot liquids (4). The sequence of events that restores damaged tissue is classified into three phases: inflammation, proliferation, and tissue remodeling (5).

Burn treatment aims to relieve pain, reduce inflammation, optimize skin regeneration and healing, and avoid possible infections, skin dehydration, and protect the burned affected area. In topical treatment, antimicrobial ointments ( $1 \%$ silver sulfadiazine, nanocrystalline silver, or also biosynthetic cures (artificial skin) (1) are used to decrease the risk of infections and reduce the treatment time of burn patients (5). Recently, in the field of complementary or alternative medicine, the activity of a wide variety of medicinal plants in the burn treatment have been reported, such as Aloe vera (L.) Burm. f, Spondias mombin L., Mentha pulegium L., among others (5-7).

Allium cepa Linnaeus., onion, is an ancient native plant from mountainous regions of Central Asia and belongs to the Amaryllidaceae family and Allium genus. It is a perennial or biennial growing plant (8). Due to its content in polyphenols, flavonoids, tannins, and vitamin $\mathrm{C}$, among other phytochemical components, Allium cepa Linnaeus has antimicrobial activity, antiplatelet activity, immune system stimulant, anti-aging, and antisclerotic properties (9). These and other active principles contained in A. cepa L. could solve problems caused by burns. Currently, there are no studies that scientifically support its topical use in this type of skin lesion, thus improving healing processes. This study assessed the wound healing activity of $A$. cepa $L$. in a seconddegree burn wound model in Holtzman rats.

\section{MATERIAL AND METHODS}

\section{Animal material}

Thirty-two specimens of Rattus norvegicus Holtzman lineage, male, three monthsold, were used. Holtzman rats were purchased at the Instituto Nacional de Salud in Lima, Peru, and housed in individual cages under standard environmental conditions with a light/ dark cycle of $12 / 12$ hours, relative humidity (70\%), ambient temperature between 22 and $24{ }^{\circ} \mathrm{C}$, fed a balanced diet, and water ad libitum. The Ethics Committee of the Faculty of Pharmacy and Biochemistry of the Universidad Nacional de Trujillo, Resolution N ${ }^{\circ}$ : IE- 008 - 2019 / C.FAC.FARM. approved this study. The Guide for the Care and Use of Laboratory Animals (10) guidelines were also followed.

\section{Plant material}

Bulbs of Allium cepa L. (onion) pink variety were used, harvested at $23 \mathrm{~m}, 8^{\circ} 24^{\prime} 51.37^{\prime \prime} \mathrm{S}, 78^{\circ} 45^{\prime} 7.52^{\prime \prime} \mathrm{W}$, in the Province of Viru, Department of La Libertad, Peru. Taxonomic identification was performed in the Herbarium Truxillense (HUT) of the Faculty of Biological Sciences of the Universidad Nacional de Trujillo with the respective taxonomic classification of the species, and a voucher specimen (HUT-N ${ }^{\circ}$ 58792) was deposited in the Herbarium HUT. Bulbs were cleaned and washed, one part was taken to prepare poultice to determine their healing activity, and another part was to prepare the extract for the corresponding phytochemical analysis.

\section{Experimental design}

\section{Phytochemical screening}

Phytochemical screening of Allium cepa L. bulbs was conducted according to the Lock methodology. Fresh onion bulbs were small cut and soaked in $200 \mathrm{~mL}$ of $95 \%$ ethanol for $48 \mathrm{~h}$, shaking the container several times a day to ensure a better extraction. It was then filtered using Whatman $N^{\circ} 1$ filter paper, after which the extract was air-dried to obtain the dry extract. One gram of dry residue was weighed, $30-\mathrm{mL}$ of solvents of different polarities were added to obtain the dichloromethane, ethanolic and aqueous extracts. Chemical identification, coloration, and/or precipitation analysis were performed to determine the presence of secondary metabolites: flavonoids (Shinoda Test), alkaloids (Dragendorff and Mayer tests), phenolic compounds (Ferric Chloride Test), saponins (Foam test), tannins (Gelatin test), anthraquinones and naphthoquinones (Bornträger test), steroids and triterpenes (Liebermann-Burchard test (11).

\section{Preparation of poultices}

Bulbs of Allium cepa L. were washed with water and salt, the outer leaves (nomophiles) were discarded, 
and the cataphiles or selected scales were crushed in mortar to prepare the poultices according to a validated method (12).

\section{Assessment of healing activity}

The upper central interscapular vertebral part of the albino rats was depilated. 24 h later, Holtzman rats were anesthetized with a mixture of ketamine hydrochloride $83 \mathrm{mg} / \mathrm{kg}$ (Fresenius Lab., Peru) and xylazine hydrochloride $17 \mathrm{mg} / \mathrm{kg}$ (Pharmadix Corp. S.A, Peru), intraperitoneally, recommended dose for rodents (13). Second-degree burn wound was induced by placing a 60-watt bulb, previously disinfected, in the dorsal subscapularis part of rats. The heat was applied three times, during 20 seconds of contact and 5 seconds of the rest interval. Most of the dermis were deformed in the burned area, but the muscle was not reached with this process. Macroscopically, the appearance was consistent with second-degree burn.

Thirty-two Holtzman rats were randomly distributed into four groups, with eight specimens per group: Healthy Group without burning, Control Group with burn and no topical treatment, received analgesic orally for pain, Experimental Group with burns, received $4 \mathrm{~g}$ /day of poultice from Allium cepa L., Standard Group with burns, received $4 \mathrm{~g} /$ day of $1 \%$ silver sulfadiazine (Medifarma Lab., Peru). The treatments were performed topically daily for 21 days, and albino rats were placed in individual cages to avoid direct contact with other animals or sources of contamination.

Measurement of wounds: the evolution of the healing process was measured by the reduction of a burned body area $\left(\mathrm{mm}^{2}\right)$ at the lateral and craniocaudal levels on the $1^{\text {st }}, 5^{\text {th }}, 9^{\text {th }}, 13^{\text {th }}, 17^{\text {th }}$, and $21^{\text {st }}$ day post-burn. Each specimen was stably placed. The wound margin was traced on a transparent plastic sheet with a fine-tipped pen; the measurement was performed using a millimeter plastic ruler to record the data later (7). This procedure was repeated every day programmed.

\section{Histopathological study}

At the end of treatment, on the $22^{\text {nd }}$ day, albino rats were sacrificed using an excess of surgical anesthesia, and skin samples were collected by making cuts of $2 \mathrm{~cm}$ long and $1.5 \mathrm{~cm}$ wide around the scar. The collected samples were placed in $10 \%$ formalin, and five days later, they were taken for the respective histopathological analysis. Haematoxylin and eosin (H\&E) were used to stain tissue sections.

\section{Statistical analysis}

Wound healing data were presented as mean \pm S.E. Two-way analysis of variance (ANOVA) was used to analyze differences between groups. Tukey's HSD test was used for post-hoc comparisons. Microsoft ${ }^{\circledR}$ Office Excel 2016 and IBM SPSS Statistics for Windows, version 20.0 (IBM Corp., Armonk, N.Y, USA) were used for data analysis. A p-value less than 0.05 was considered statistically significant.

\section{RESULTS}

\section{Qualitative phytochemical screening}

Qualitative phytochemical analysis of bulbs from Allium cepa L. revealed different secondary metabolites, which could be the active principles responsible for the healing activity. These phytoconstituents, present in different intensities, depending on the type of solvent used, from lower to higher polarity to optimize the extraction and identification processes of these active ingredients, are detailed in Table 1.

Table 1. Phytochemical screening of Allium cepa L. bulbs

\begin{tabular}{lllll}
\hline \multicolumn{5}{c}{ Allium cepa L. extracts } \\
\hline Secondary metabolites & \multicolumn{1}{c}{ Test's name } & DM & E & A \\
\hline Tannins & Gelatin & - & ++ & + \\
Steroids & Lieberman-Burchard & + & - & - \\
Flavonoids & Shinoda & + & + & - \\
Alkaloids & Mayer & - & + & + \\
& Dragendorff & + & + & + \\
Saponins & Foam & - & - & - \\
Phenols & Ferric Chloride & ++ & + & - \\
Quinones & Bornträger & - & - & - \\
\hline
\end{tabular}

DM: dichloromethane extract, E: ethanolic extract, $\mathrm{A}$ : aqueous extract.

Presence and intensity: (-): absence; $(+)$ : few; $(++)$ : moderate; $(+++)$ : abundant

\section{Wound healing activity assessment}

Evolution in reduction of body area injured by burns in albino rats is shown in Figure 1. In the experimental group (Allium cepa L.), the wound size decrease and ongoing healing were significant $(p<0.05)$ compared with the control group. The reduction happened since the $9^{\text {th }}$ day after the burn induction. This reduction in burned body area was more evident on the $21^{\text {st }}$ day. We found a statistically highly significant difference $(p<0.01)$ in the decrease in size burn-wounds of the experimental group (Allium cepa L.) concerning the control group and, similar to the standard group that received topical silver sulfadiazine cream. 


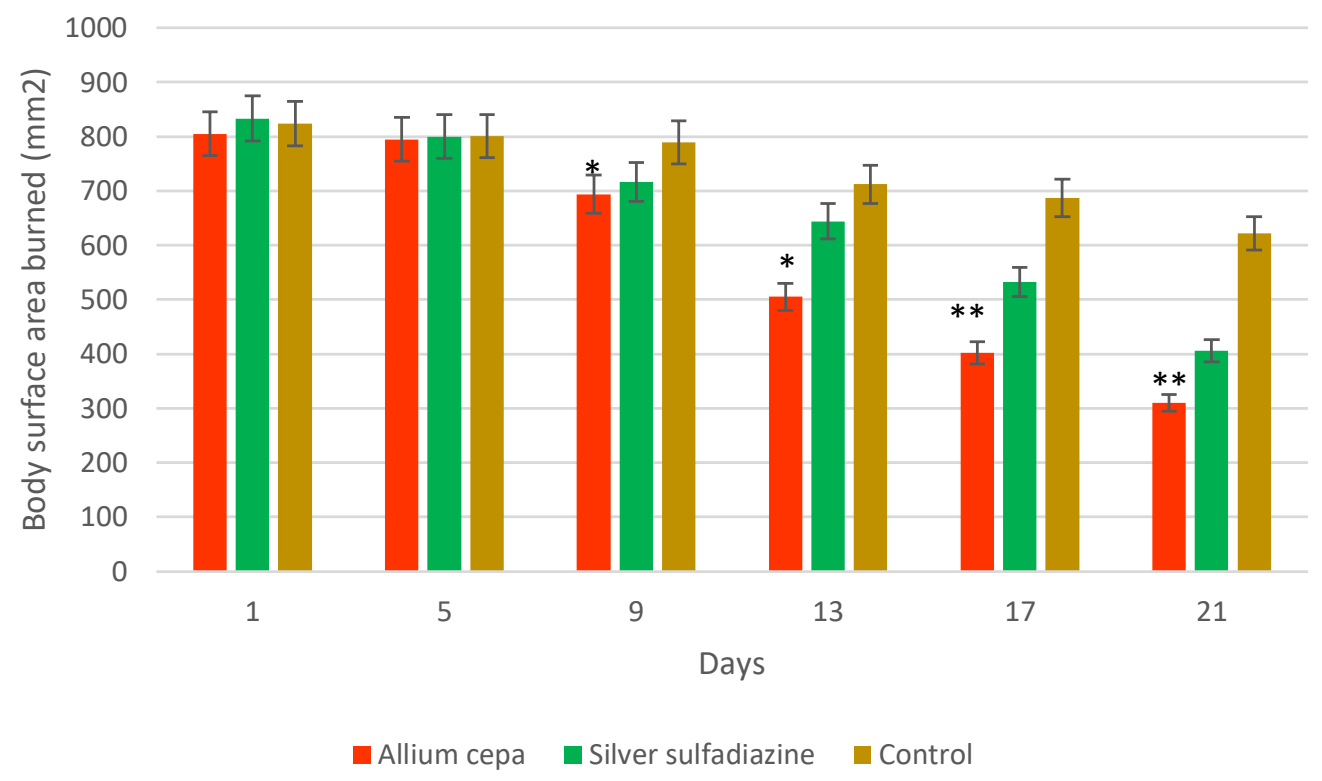

Figure 1. The average reduction of body areas with induced burns in Holtzman rats. Values in each group $(n=8)$ were expressed as the mean \pm S.D.M. (two-way analysis of variance/post hoc Tukey's HSD); $p<0.05, * \star p<0.01$ : represented a highly significant statistical difference compared to the control group.

\section{Histopathological changes}

The histopathological study of rat's skin in standard, experimental, and control groups showed changes related to the presence of fibroblasts, angiogenesis processes, macrophages, collagen, and morphological changes. The difference between the healthy skin, intact and without lesions, concerning the other groups, especially the control group, was evident.
A

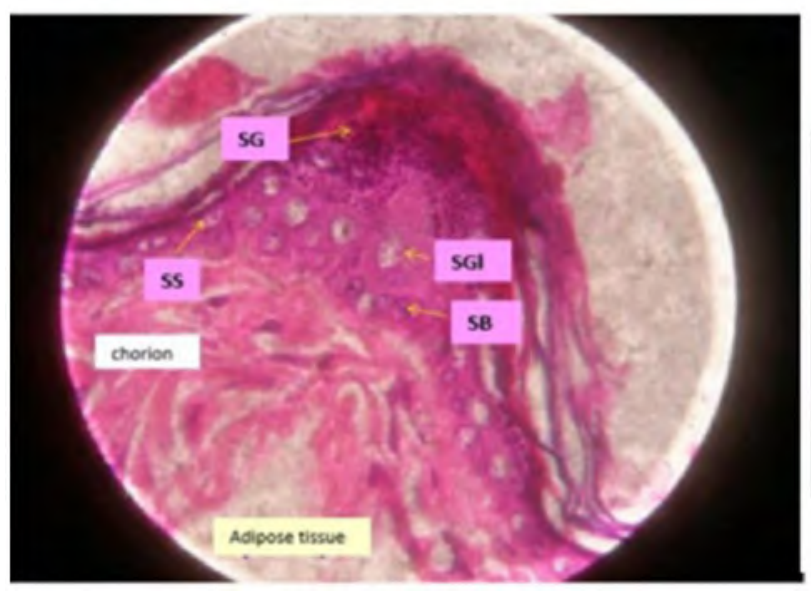

B

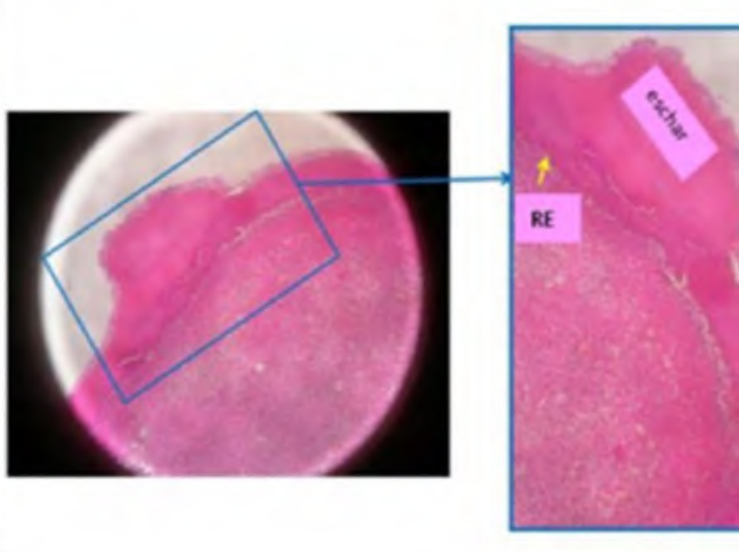

Figure 2. The rat skin. A) Healthy group. No burn, normal dermis. Stratum granulosa (SG), typical cells of the stratum spinosum (SS), cells of the stratum basalis (SB), sebaceous glands (SGL) were also observed. H\&E 400X. B) Control group. The top layer of coagulated blood, fibroblasts, blood vessels, and possible re-epithelialization (RE). H\&E 100X. 
C

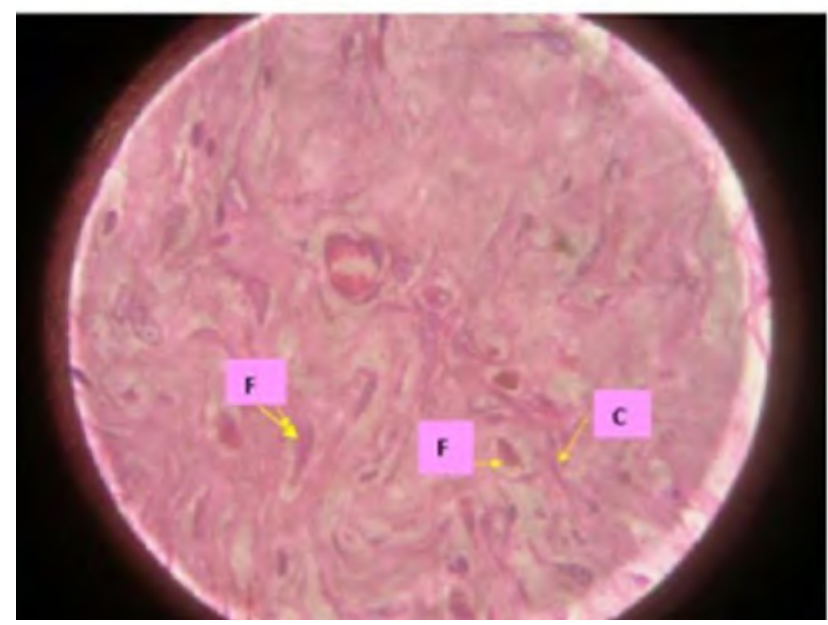

D

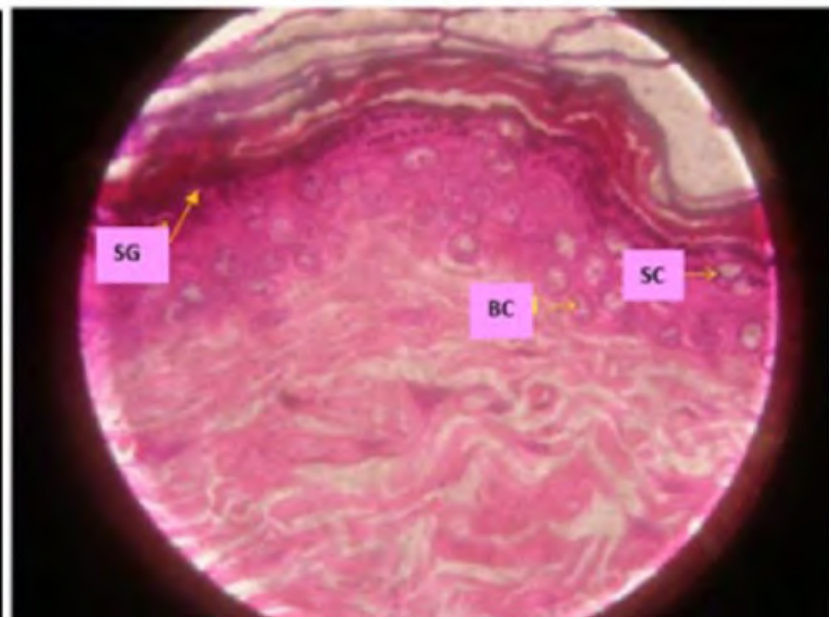

Figure 3. The rat skin. C) Standard Group (Silver sulfadiazine). Dermis: deep zone. Fibroblast (F) and blood vessels decreased. Arrangement of collagen (C) in mesh, indicating lesion contraction. H\&E 400X. D) Experimental Group (Allium cepa L.). The epidermis in recovery. Stratum granulosa (SG), spiny cells (SC), and basal cells (BC). The dermis was made up of a reticular layer of fibroblasts, collagen, and few blood vessels. H\&E 400X.

\section{DISCUSSION}

Phytochemical analysis of Allium cepa L. bulbs revealed tannins, flavonoids, steroids, and phenols (Table 1), which could be responsible for the healing activity of this plant. Several studies report that onion is one of the major sources of flavonoids in the diet, and they are considered dietary phytoconstituents with high antioxidant activity $(14,15)$. These secondary metabolites were also reported in other studies of the genus Allium, and from Allium cepa L. specifically (16-18). Additionally, alkaloids are related to antibacterial and analgesic activities (16), while flavonoids and tannins contribute to antioxidant activity and free radicals' scavengers $(18,19)$. All these aspects could participate and optimize the wound healing activity of Allium cepa L. bulbs.

The reduction in wound size and ongoing healing were observed evolutionarily, becoming more evident in the experimental group (Allium cepa L.) since the $9^{\text {th }}$ day from the beginning of the study (Fig.1). These results agree with those reported in the study conducted with extractum cepae, heparin, allantoin gel, and silver sulfadiazine in experimental burns. The scabs began to form on the $7^{\text {th }}$ day of the study (20). It was also evident that the healing effects of silver sulfadiazine and the natural product A. cepa L. were similar, and there was no significant difference ( $p>0.05$ ) between these groups. Silver sulfadiazine $1 \%$ has antimicrobial, analgesic, low toxicity, and sensitization properties, optimizing its use for burns $(5,21)$.
Allium cepa L. showed significant improvement in the healing processes of burns in albino rats, which can be attributed to its active principles such as polyphenol compounds, flavonoids, and mainly quercetin and its glycosides, as reported in various studies $(19,22)$. Additionally, essential oils and tannins report antioxidant, anti-inflammatory, antibacterial, and antifungal activity, preventing the proliferation of microorganisms $(19,22)$. Likewise, it has been reported that onion contains ferulic acid, p-coumaric acid, protocatechical acid, and catechol (9). These non-flavonoid polyphenols, with flavonoids, possess powerful antioxidant and free radical scavenger activity, which would favor the healing process (19).

The morphological characteristics of the skin of the healthy group (Fig.2 A) contrasted with the damage that occurred in the burned skin of the control group (Fig.2 B). The inflammation, hyperemic chorion, and fibroblasts were evident, presence of blood vessels and, in the upper part, the forming crust (layer of coagulated blood) protrudes. There was also evidence of a gradual re-epithelialization process, consistent with that reported in studies with Extractum cepae and Pistacia lentiscus L. $(20,23)$. Likewise, our results agreed with the study conducted with Hypericum perforatum L. in which the wound healing process was not completed in the control group, the presence of eschar and reepithelization was limited to the beginning zones (24). The healing processes generally begin one day after the injury, when the inflammatory process is still underway, 
proliferating fibroblasts and endothelial cells, which after 3 to 6 days, form a specialized tissue, called granulation tissue, essential for wound healing (25).

The standard group (silver sulfadiazine) showed a decrease in the number of fibroblasts and blood vessels. This finding corresponded to a healing period of more than two weeks, with the presence of fibroblasts, collagen, and contraction of the affected area (Fig. 3 C). Our result agreed with those reported with Mentha pulegium L. and extractum cepae $(7,20)$. Alternatively, poultices from the bulbs of Allium cepa L. (onion) produced epidermis recovery in the injured tissue (Fig.3 D), observing spiny and basal cells, and the dermis showed an aligned reticular layer of fibroblasts, collagen, and few blood vessels. Fibroblasts' presence could indicate that the natural product promoted skin regeneration and optimize the wound healing process (26); therefore, the alignment and increase of collagen fibers optimized the wound healing (27). Flavonoids, tannins, and alkaloids are related to the healing process by increasing collagen viability as it improves collagen fibers' resistance (28).

The phytochemical compounds of onion, such as quercetin and flavones such as luteolin, and kaempferol, favor the wound healing process due to their antioxidant activity $(29,30)$. Likewise, this antioxidant activity, at least in part, can be attributed to Allium cepa L. polyphenolic compounds, which could optimize the wound-healing activity. The results agreed with the healing properties attributed to Tragopogon graminifolius DC, which contained polyphenolic compounds like p-coumaric acid, ferulic acid, and caffeic acid, secondary metabolites also included in the onion bulbs (31). Antioxidant activity of Allium cepa L. would be reinforced by vitamin $C(9)$, which plays an essential role in processes such as healing. So, vitamin $\mathrm{C}$ deficiency can delay healing, increase inflammatory processes, among other alterations $(32,33)$. Currently, there is evidence that Allium cepa L. shows therapeutic effects in the human skin fibroblast cell line and is used to treat keloids and postsurgical lesions $(34,35)$.

With the results found in our research, we contribute significantly to give scientific support to consider preparations containing Allium cepa L. pink variety as a new alternative treatment for burns.

\section{CONCLUSION}

Allium cepa L. revealed wound healing activity on burns induced in Holtzman rats and reduced the damage produced by burns. Thus, such a natural product may represent a potential treatment candidate for burns. Further studies that aim to elucidate the exact mechanism of action and identify the active components would be additional steps in developing pharmaceutical candidates from Allium cepa L. for burns treatment.

\section{AUTHORS' CONTRIBUTIONS}

All authors have actively participated in all processes of development of this research and writing of this article.

\section{CONFLICTS OF INTEREST}

The authors declare no conflicts of interest.

\section{REFERENCES}

1. Lukiswanto BS, Miranti A, Sudjarwo SA, Primarizky $H$, Yuniarti WM. Evaluation of wound healing potential of pomegranate (Punica granatum) whole fruit extract on skin burn wound in rats (Rattus norvegicus). J Adv Vet Anim Res. 2019; 6(2):202-207. DOI: http://doi.org/10.5455/javar.2019.f333

2. Schencke C, Vasconcellos A, Salvo J, Veuthey C, Del Sol M. Efecto cicatrizante de la miel de ulmo (Eucryphia cordifolia) suplementada con ácido ascórbico como tratamiento en quemaduras. Int. J. Morphol. 2015; 33(1):137-143. DOI: http:// dx.doi.org/10.4067/S0717-95022015000100022

3. World Health Organization. Burns [Internet], https://www.who. int/es/news-room/fact-sheets/detail/burns 2020 (accessed 06 December 2020).

4. ANDINA. Agencia peruana de noticias. Cada año se reportan en Perú unos 15,000 casos de niños quemados. [Internet], https://andina.pe/agencia/noticia-cada-ano-se-reportan-peruunos-15000-casos-ninos-quemados-757545.aspx 07/11/2019 (accessed 08 December 2020)

5. Akhoondinasab MR, Akhoodinasab M, Saberi M. Comparison of healing effect of Aloe vera extract and silver sulfadiazine in burn injuries in experimental rat model. World J Plast Surg 2014; 3(1):29-34. Available from: https://www.ncbi.nlm.nih.gov/pmc/ articles/PMC4236981/

6. Lozada D. Recuperación de la integridad de la piel en ratas inducidas a quemaduras tratadas con extracto hidroalcohólico de Spondias mombin (Ulcos). 2020. [Grade Work]. [Lima, Peru]: Universidad María Auxiliadora. 2020. 88 p. Available from: http:// repositorio.uma.edu.pe/handle/UMA/226

7. Vaghardoost R, Ghavami y, Sobouti B. The effect of Mentha pulegium on healing of burn wound injuries in rat. World J Plast Sur. 2019; 8(1):43-50. Available from: https://www.ncbi.nlm.nih. gov/pmc/articles/PMC6409140/

8. Cueto T. Situación fitosanitaria de la cebolla roja (Allium cepa), en Barranca. [Grade Work]. [Lima, Peru]: Universidad Nacional de La Molina. 2017.48 p. Available from: http://repositorio.lamolina. edu.pe/handle/UNALM/2958

9. Bystricka J, Musilova J, Vollmannova A, Timoracka M, Kalcova P. Bioactive components of onion (Allium cepa L.)- A review. Acta Alimentaria. 2013; 42(1):11-22. DOI: https://doi.org/10.1556/ aalim.42.2013.1.2 
10. National Research Council (US) Committee for the Update of the Guide for the Care and Use of Laboratory Animals. Guide for the Care and Use of Laboratory Animals. [Internet] 8th ed. Washington DC. National Academies Press (US). 2011. [Cited 2020 December 16].220p. Available from: https://www.ncbi.nlm. nih.gov/books/NBK54050/

11. Lock O. Investigación fitoquímica. Métodos en el estudio de productos naturales. $3^{\mathrm{a}}$ ed., Fondo Editorial Pontificia Universidad Católica del Perú, Lima; 2013. 287p.

12. Gennaro A. Remington: Farmacia.Tomo.1. 20 ed., Médica Panamericana S.A, Buenos Aires; 2003.3894p.

13. Hawk CT, Leary S, Morris T. Formulary for laboratory animals. [Internet]. lowa: Backwell Publishing; 2005 [cited 2021 January 27]. 196 p. Available from: https://www.upstate.edu/iacuc/pdf/ Formulary_for_Lab_Animals_3rd_ed.pdf

14. Corzo Martínez M, Corzo N, Villamiel M. Biological properties of onion and garlic. Trends Food Sci. Technol.2007; 18(12):609-625. DOI: https://doi.org/10.1016/j.tifs.2007.07.011

15. Rodríguez Galdón B, Rodríguez Rodríguez E, Díaz Romero C. Flavonoids in onion cultivars (Allium cepa L.). J Food Sci. 2008;3(8):C599-605. DOI: https://doi.org/10.1111/j.17503841.2008.00903.x

16. Dalhat M, Adefolake F, Musa M. Nutritional composition and phytochemical analysis of aqueous extract of Allium cepa (onion) and Allium sativum (garlic). Asian Food Science Journal. 2018; 3(4): 1-9. DOI: https://doi.org/10.9734/AFSJ/2018/43165

17. Boukeria S, Kadi K, Kalleb R, Benbott A, Bendjedou D, Yahia A. Phytochemical and physicochemical characterization of Allium sativum L. and Allium cepa L. Essential oils. J. Mater Environ. Sci. 2016 ; 7(7):2240-2257. Available from: https://www. jmaterenvironsci.com/Document/vol7/vol7_N7/254-JMES-2066Boukeria.pdf

18. Farag M, Ali S, Hodaya R, El-Seedi H, Sultani H, Laub A, et al. Phytochemical orofiles and antimicrobial activities of Allium cepa Red cv. and A. sativum subjected to different drying methods: A comparative MS-Based metabolomics. Molecules.2017; 22(5):761. DOI: https://doi.org/10.3390/molecules22050761

19. Shenoy C, Patil MB, Kumar R, Patil S. Preliminary phytochemical investigation and wound healing activity of Allium cepa (Liliaceae). Int J Pharm Pharm Sci. 2009;1(2):167-175. Available from: https:// innovareacademics.in/journal/ijpps/Vol11ssue2/208.pdf

20. Durmus A, Yaman M, Can H. Effects of extractum cepae, heparin, allantoin gel and silver sulfadiazine on burn wound healing: an experimental study in a rat model. Vet Med (Praha). 2012;57(6):287-292. DOI: https://doi.org/10.17221/6015-VETMED

21. Kimura Y, Sumiyoshi M, Kawahira K, Sakanaka M. Effect of ginseng saponins isolated from Red Ginseng roots on burn wound healing in mice. Br J Pharmacol. 2000; 148(6):860-870. DOI: https://doi.org/10.1038/sj.bjp.0706794

22. Upadhyay R. Nutraceutical, pharmaceutical and therapeutic uses of Allium cepa: A review. Int. J. Green Pharm. 2016 (Suppl). 10(1): S46-S64. DOI: http://dx.doi.org/10.22377/ijgp.v10i1.612
23. Ben-Kedir S, Bardaa S, Chabchoub N, Moalla D, Sahnoun Z, Rebai T. The healing effect of Pistacia lentiscus fruit oil on laser burn. Pharm Biol. 2017; 55(1):1407-1414. DOI: https://doi.org/10.1080/ 13880209.2016.1233569

24. Egri, Ö, Erdemir N, Gevrek F. Effect of H. perforatum oil containing membranes on the second degree burn wounds in rats. Mater Today Commun. 2020; Vol. 24, 100954. DOI: https:// doi.org/10.1016/j.mtcomm.2020.100954

25. Alca, E, Del Solar M, Bravo F. Efecto de la xantopterina en la cicatrización de heridas por quemaduras en ratas. Folia Dermatol. 2009; 20(1):13-17. Available from: https://sisbib.unmsm.edu.pe/ BVRevistas/folia/vol20_n1/pdf/a03v20n1.pdf

26. Bayir Y, Un H, Ugan R, Akpinar E, Cadirci E, Calik I, et al. The effects of Beeswax, Olive oil and Butter impregnated bandage on burn wound healing. Burns. 2019; 45(6):1410-1417. DOI: https:// doi.org/10.1016/j.burns.2018.03.004

27. Tsala D, Joseph M, Simplice T, Nga N, Jacques E, David M. Effect of methanol extract of Allium cepa Linn. on incisional wound healing in alloxan-induced diabetic mice. Appl Med Res. 2015; 1(3):90-93. DOI: https://dx.doi.org/10.5455/amr.20150427021827

28. Tuhin R, Begum M, Rahman M, Karim R, Begum T, Ahmed S, et al. Wound healing effect of Euphorbia hirta Linn. (Euphorbiaceae) in alloxan induced diabetic rats. BMC Compl Alternative Med. 2017; 17(1), 423. DOI: https://doi.org/10.1186/s12906-017-1930-x

29. Lanzotti $\mathrm{V}$. The analysis of onion and garlic. J Chromatogr A. 1112 (1-2): 3- 22. DOI: https://doi.org/10.1016/j.chroma.2005.12.016

30. Jaiswal N, Kumar D, Rizvi S. Red onion extract (Allium cepa L.) supplementation improves redox balance in oxidatively stressed rats. Food Sci. Hum. Wellness. 2013; 2(2):99-104. DOI: https:// doi.org/10.1016/j.fshw.2013.05.003

31. Heidari M, Bahramsoltani $R$, Abdolghaffari A, Rahimi R, Esfandyari M, Baeeri M, et al. Efficacy of topical application of standardized extract of Tragopogon graminifolius in the healing process of experimental burn wounds. J Tradit Complement Med. 2019; 9(1):54-59. DOI: https://doi.org/10.1016/j.jtcme.2018.02.002

32. MacKay D, Miller A. Nutritional support for wound healing. Altern Med Rev. 2003; 8(4):359-377. Available from: https://pubmed. ncbi.nlm.nih.gov/14653765/

33. Fain O. Vitamin C deficiency. Revue Med Interne. 2004; 25:872880. DOI: https://doi.org/10.1016/j.revmed.2004.03.009

34. Pikula M, Zebrowska ML, Poblocka-Olech L, Krauze-Baranowska M, Sznitowska M, Trzonkowski P. Effect of enoxaparin and onion extract on human skin fibroblast cell line- therapeutic implications for the treatment of keloids. Pharm Biol. 2014; 52(2):262-267. DOI: https://doi.org/10.3109/13880209.2013.826246

35. Zurada J, Kriegel D, Davis I. Topical treatments for hypertrophic scars. J Am Acad Dermatol 2006; 55(6):1024-1031. DOI: https:// doi.org/10.1016/j.jaad.2006.03.022 